\title{
RESEARCH NOTEBOOKS \\ Developing Students' Critical Thinking Skills in KAETSU ARIAKE Junior \& Senior High School library
}

\author{
Shoko Sanada \\ Kaetsu Ariake Junior \& Senior High School \\ 2-16-1 Shinonome, Koto-Ku, Tokyo \\ Japan, \\ sanada@ariake.kaetsu.ac.jp \\ Hideo Yamada \\ Kaetsu Ariake Junior \& Senior High School \\ 2-16-1 Shinonome, Koto-Ku, Tokyo \\ Japan, \\ yamada@ariake.kaetsu.ac.jp \\ Aiko So \\ FUJIMI Junior \& Senior High School \\ 4-8-26 Nakamurakita, Nerima-ku, Tokyo \\ Japan, \\ a.sou@fujimi.ac.jp \\ Terumi Kuwata \\ Kokushikan University \\ 1-1-1 Hirohakama, Machida-shi, Tokyo \\ Japan, \\ tkwuata@kokushikan.ac.jp
}

\begin{abstract}
We, Kaetsu Ariake, regard 21st century skills as one of the most important factors for our students to acquire. Especially, critical thinking (CT) and its skills are indispensable. Thus, we offer special classes for the 7th, 8th, and 9th grade students to become better thinkers. Teachers from a variety of subjects teach the classes, which are held in our school library with the help of its librarian. The librarian teaches the students library skills, supports the teachers, and edits the Research Notebooks. The Research Notebooks are the key to managing the three-year course. We refer to the six-step learning program and Revised Bloom's Taxonomy in order to develop the Research Notebooks. Using the Notebooks, the
\end{abstract}


students can develop good insights and skills to do research. By making use of the library, getting the help of the librarian, and using the Research Notebooks, we promote 21 st century skills throughout our school.

Keywords: Critical thinking, 21st Century Learning, Bloom's Taxonomy, Big6 skills, Library instruction, Inquiry-based Learning, Research Skills

At Kaetsu Ariake, we are very proud of our school library. The library has been designed to support the students' education by providing them with an area in which they can learn autonomously, actively, and critically.

In our school, we place a particular focus on critical thinking (CT). As well as incorporating CT skills throughout the regular curriculum, at Kaetsu Ariake, we have special classes dedicated to developing necessary approaches, attitudes, and mind-sets which will help students become better thinkers. These classes are held in our school library, and the library, along with its librarian, play critical roles in helping to foster indispensable $21^{\text {st }}$ century CT skills.

The library itself is set up with teaching areas equipped with interactive whiteboards connected to the internet. The teaching areas can be booked by any subject teacher, but they are mainly used for our three-year critical thinking skills training course, taught in junior high. These CT skills lessons are held twice a week for the 7th and 8th grade students, and once a week for the 9th grade students. The majority of the lessons for the CT course are conducted with the help of the librarian. In the first few lessons, she teaches the students useful library skills, and throughout the three years, she supports the teachers and edits the Research Notebooks(Figure 1) that accompany the program.

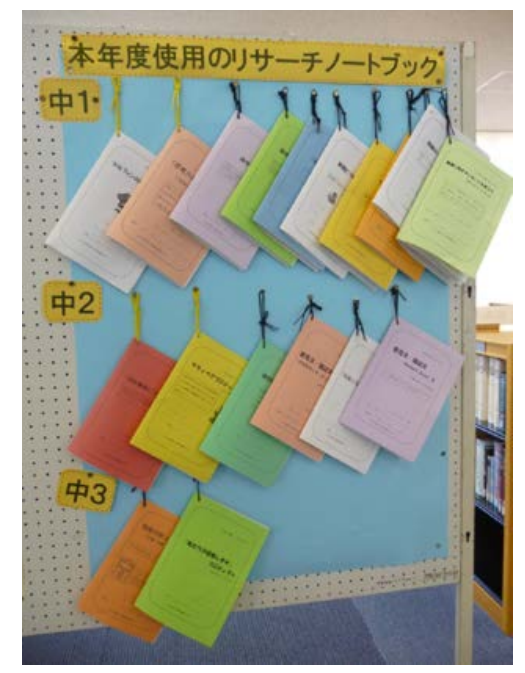

Figure 1: Research Notebooks 
The Research Notebooks are the key to successfully managing the course. Referring to the six-step learning program and Revised Bloom's Taxonomy, the librarian and the teachers prepare the Research Notebooks for each grade. The structure of the Notebooks sets the students on a path to acquiring good research skills by following a six-step procedure: Decide the theme, focus on the target, collect the necessary information, analyze the information, express it logically, and evaluate the results.

In the process of the research, students are trained with CT skills based on the cognitive levels in the Revised Bloom's Taxonomy. These crucial skills include library skills, fact-opinion differentiation skills, comparing-contrasting skills(Figure 2), cause-effect reasoning skills, presentation skills, and so on.

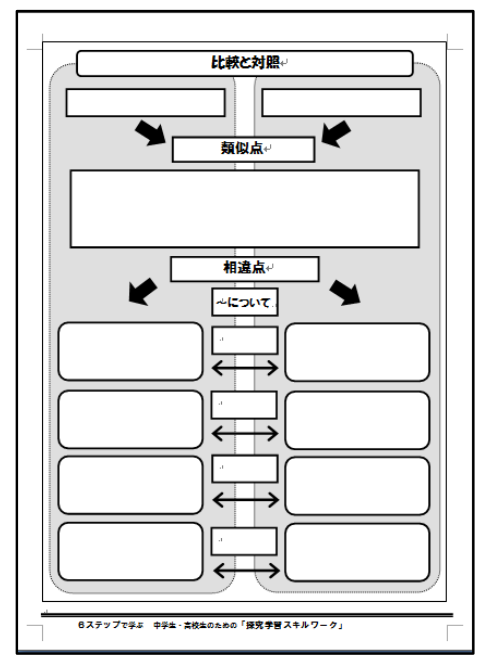

Figure 2: Graphic Organizer - Compare and contrast

With the Research Notebooks, the teachers and the librarian conduct skill training lessons with yearly objectives. In the first year, students are trained to focus on how to collect necessary information; in the second year, they analyze the collected data; and in the third year, they create and give engaging class presentations.

Altogether, by making effective use of the library, and collaborating with our excellent librarian, we have been able to create a unique three-year critical thinking course, which combined with the Research Notebooks, have been instrumental in promoting important $21^{\text {st }}$ century skills throughout our school.

\section{References}

Anderson, L.W., Krathwohl, D.R., Airasian, P.W., Cruikshank, K.A., Mayer, R.E., Pintrich, P.R., Raths, J., Wittrock, M.C. (2001). A Taxonomy for Learning, Teaching, and Assessing: A 
revision of Bloom's Taxonomy of Educational Objectives. New York: Pearson, Allyn \& Bacon.

Bloom, B. , Englehart, M. , Furst, E. , Hill, W. , \& Krathwohl, D. (1956). Taxonomy of educational objectives: The classification of educational goals. Handbook I: Cognitive Domain. New York: Longmans Green.

Eisenberg, M. B. \& Berkowitz, R. E. (1999). Teaching information \& technology skills: The Big6 in elementary schools. Worthington, Ohio: Linworth.

Eisenberg, M. B. \& Berkowitz, R. E. (2000). Teaching information \& technology skills: The Big6 \& in secondary schools. Worthington, Ohio: Linworth.

Murray, J. R. (2007). Achieving educational standards using the Big6. Worthington, Ohio: Linworth.

Parks, S. \& Black, H. (1992). Organizing thinking: book II: graphic organizers. Pacific Grove, Calif : Critical thinking books \& software.

Partnership for 21st Century Learning. (2007). Framework for 21st century learning. [ONLINE] Available at: http://www.p21.org/about-us/p21-framework. [Accessed 25 May 2016].

今泉浩晃. (1998). マンダラMEMO学: Mandal-Art脑のOSを創る. オーエス出版.

\section{桑田てるみ編. (2012). 6 プロセスで学ぶ中学生・高校生のための探究学習スキルワーク.} 全国学校図書館協議会.

山田英雄. (2011). かえつ有明サイエンス科プログラム基本コンセプト. かえつ有明中高等学校カリキュラム研究開発実施報告書＼cjkstart平成 23 年版 93-100.

\section{Biographical note}

Author 1: Shoko Sanada has worked as School Librarian at Kaetsu Ariake Junior \& Senior High School in Japan

Author 2: Hideo Yamada has worked as a Japanese teacher of English at Kaetsu Ariake Junior \& Senior High School in Japan.

Author 3: Aiko Nomura has worked as School Librarian at Den-en Chofu Gakuen Junior \& Senior High School in Japan

Author 4: Terumi Kuwata has worked as professor at Kokushikan University 